\title{
Antimicrobial activity of the volatile phase of essential oils and their constituents on Legionella pneumophila
}

\author{
Lucia BIĆANIĆ ${ }^{1}$, Silvestar MEŽNARIĆ ${ }^{1}$, Ivana GOBIN ${ }^{2}$
}

\begin{abstract}
Pathogenic bacteria of the genus Legionella cause atypical pneumonia known as Legionnaires' disease and flu - like disease known as Pontiac fever. As pathogens of the respiratory system, these bacteria represent a public health problem and there is a need for examine new alternative ways to inactivate them. These bacteria live naturally in water and are transmitted by infectious aerosols. To purify the air, essential oils that show antimicrobial properties are widely used. The anti-Legionella activity of five exotic essential oils and five Mediterranean essential oils characteristic for coastal Croatia was examined. Model organism used in experiments was L. pneumophila (strain 130b). This experiment was conducting with modified version of sealed plate method using a BCYE medium. The exotic essential oil with highest anti-Legionella activity was Niaouli essential oil, and the best anti-Legionella activity among Mediterranean essential oils showed Immortelle essential oil. Anti- Legionella activity of four main chemical compounds was examined and compound that show significant highest anti-Legionella activity was $\alpha$ - pinene. Volatile components of essential oils have a great potential as anti-Legionella agents and further research are needed.
\end{abstract}

Key words: essential oils; volatile components; Legionella; antibacterial effect

\section{POVZETEK}

Patogene bakterije iz rodu Legionella povzročajo atipično pljučnico, poznano pod imenom Legionarska bolezen in Pontiaška vročica. Tako kot drugi povzročitelji bolezni respiratornega sistema tudi te bakterije predstavljajo javnozdravstveni problem. Iz tega sledi nenehna potreba po iskanju novih alternativnih načinov preprečevanja in obvladovanja njihovega pojava. Bakterije iz rodu Legionella lahko najdemo $v$ naravnih in umetnih vodnih sistemih, prenašajo pa se preko onesnaženih aerosolov. Za čiščenje zraka se pogosto uporabljajo eterična olja, ki delujejo protimikrobno. Z uporabo BCYE medija smo analizirali protimikrobno delovanje na bakterijo Legionella pneumophila (sev 130b). Pri tem je bilo testiranih pet eksotičnih eteričnih olj in pet sredozemskih eteričnih olj, značilnih za obalo Hrvaške. Med eksotičnimi
Original scientific article

Received: 29. 02. 2020

Accepted: 30. 12. 2020

Published: 31. 12. 2020

${ }^{1}$ Student at Faculty of Medicine, University of Rijeka, Brace Branchetta 20, 51000 Rijeka, Croatia

${ }^{2}$ Department of Microbiology and Parasitology, Faculty of Medicine, University of Rijeka, Braće Branchetta 20, 51000 Rijeka, Croatia

* Corresponding author Ivana Gobin, PhD, Associate professor Department of Microbiology and Parasitology, Faculty of Medicine, University of Rijeka, Brace Branchetta 20, 51000 Rijeka, Croatia

E-mail: ivana.gobin@uniri.hr

(C) 2020 Lucia Bićanić, Silvester Mežnarić, Ivana Gobin. This is an open access article licenced under the Creative Commons Attribution NonCommercialNoDerivs license as currently displayed on http://creativecommons.org/licenses/ by-nc-nd/4.0/. 
eteričnimi olji smo največjo protimikrobno aktivnost zabeležili pri olju »Niaouli«. Med sredozemskimi eteričnimi olji pa je bilo to olje »lmmortelle«. Med glavnimi kemičnimi snovmi ima največji antibakterijski učinek spojina $\alpha$ - pinen. Velik potencial antimikrobnega delovanja hlapnih snovi eteričnih olj na bakterijo Legionella pnemuophila kaže potrebo po nadaljnjih raziskavah.

Ključne besede: eterična olja; hlapne snovi; Legionella; antibakterijski učinek

\section{INTRODUCTION}

The genus Legionella contain a group of pathogenic bacteria that very often cause respiratory diseases collectively called legionellosis. Species from the genus Legionella belong to the family Legionellaceae, and the main cause of most legionellosis is Legionella pneumophila. Legionellosis has two forms: Pontiac fever and Legionnaires' disease. Legionnaires' disease or atypical pneumonia is a very common and severe systemic disease. Another mild legionellosis that has flu-like symptoms is known as Pontiac fever $[1,2]$. The largest, natural habitat of $L$. pneumophila is freshwater environment and very often can be present in various artificial and natural water systems such as cooling towers, air conditioners, humidifiers and dehumidifiers, boilers, swimming pools, fountains and other water systems [3]. The most common cases of infection with this bacterium are associated with travel and staying in different hotels [4]. For this reason, it is important to prevent the presence of this bacteria in places where people are gathering, so that epidemics do not occur. One of such important places are hotels and spa centers where water analysis must be performed regularly, and measures must be taken to prevent legionellosis.

Essential oils are composed of volatile molecules and are produced from aromatic or medicinal plants by a process of secondary metabolism. The largest share, in essential oils, are aromatic hydrocarbons and terpenes, which give them their characteristic pleasant and intense odor. It is very important to note that when isolating oil from the same plant and the same process, do not always results with oil that have the same composition, it will largely depend on various factors such as growth and cultivation conditions and the time of harvesting the plant itself. EOs are usually obtained as a result of hydrodistillation, steam distillation, dry distillation, or the mechanical cold pressing of plants [5]. Essential oils have been used for thousands of years, not only as ingredients of perfumes or for the aromatization of food, but also in folk medicine, because of their many different biological properties, including antimicrobial properties.

The aim of this study was to determine the antimicrobial activity of volatile phase of different Mediterranean and exotic essential oils and their active volatile components.
The largest, natural habitat of L. pneumophila is freshwater environment and very often can be present in various artificial and natural water systems such as cooling towers, air conditioners, humidifiers and dehumidifiers, boilers, swimming pools, fountains and other water systems.

Essential oils are composed of volatile molecules and are produced from aromatic or medicinal plants by a process of secondary metabolism. 
Essential oils have been used for thousands of years, not only as ingredients of perfumes or for the aromatization of food, but also in folk medicine, because of their many different biological properties, including antimicrobial properties.

\section{MATERIALS AND METHODS}

\section{Model organism}

Model organism used in experiments was $L$. pneumophila serogroup 1 , strain 130b or ATCC BAA-74 (clinical isolate). This bacterial strain was obtained from the collection of the Department of Microbiology and Parasitology, University of Rijeka. The bacterium was kept in $10 \%$ glycerol broth, stored in a freezer at $-80{ }^{\circ} \mathrm{C}$. After cultivation for $3-5$ days on buffered charcoal yeast extract (BCYE) agar (Oxoid, Altrincham, UK) at 35 $\pm 2{ }^{\circ} \mathrm{C}$ in an aerobic atmosphere, the bacterium was used in experiments.

\section{Essential oils and their basic chemical components}

The essential oils were obtained from the company Dea Flores d.o.o. (Rijeka, Croatia) and a stock solution of essential oil was prepared using DMSO (dimethylsulfoxide) (Kemika, Zagreb, Croatia) in a concentration of $100 \mathrm{mg} / \mathrm{mL}$. The tested oils were divided into two groups. The first group consists of exotic essential oils: Spikenard (Nardostachys jatamansi), Niaouli (Melaleuca quinquenervia), Hysssop (Hyssopus officinalis), Palmarosa (Cymbopogon martinii) and Ravensara (Ravensara aromatica). The second group consists of essential oils from coastal region of Croatia: Juniper berry (Juniperus communis), Immortelle (Helichrysum italicum), Sage (Salvia officinalis L.), Lavander (Lavandula $x$ hybrida) and Rosemary (Rosmarinus officinalis). The antibacterial activity of bioactive components of the essential oils $\alpha$-pinene, $\beta$-pinene, $\gamma$-terpinene and eugenol (Sigma-Aldrich, MO, USA) were also tested. The concentration of the stock suspension was $200 \mathrm{mg} / \mathrm{mL}$.

\section{Preparation of bacterial inoculum}

The number of bacteria in bacterial suspension was determined spectrophotometrically. The optical density of bacterial suspension was set to $\mathrm{OD}_{600}$ value 1,0 which indicates $10^{9} \mathrm{CFU} / \mathrm{mL}$. The bacterial concentrations of approximately $1 \times 10^{8} \mathrm{CFU} / \mathrm{mL}$ were used in the experiments. The number of bacteria in the inoculum was confirmed by cultivation of ten-fold dilutions on BCYE medium.

\section{Determination of the antimicrobial activity of volatile components by sealed plate method}

Modified version of sealed plate method has been used [6]. Briefly, using a sterile swab, bacteria suspension $\left(10^{8} \mathrm{CFU} / \mathrm{mL}\right)$ were spread evenly onto pre-warmed $37{ }^{\circ} \mathrm{C}$ BCYE agar plates. A $5 \mathrm{~mm}$ diameter cellulose disc soaked with $5 \mu \mathrm{L}$ of the test essential oil or tested components was then placed in the center of each lid of the Petri dish. To set up the assay the bottom of plate containing the bacteria was inverted over the plate carrying volatile compound and was sealed against each other tightly using petri-seal to prevent the essential oil from evaporating outside the Petri dish. The BCYE agar were then placed in a thermostat at $35 \pm 2{ }^{\circ} \mathrm{C}$ for a 72 -hour incubation. Plates without volatiles served as control. After a 72-hour incubation, the 

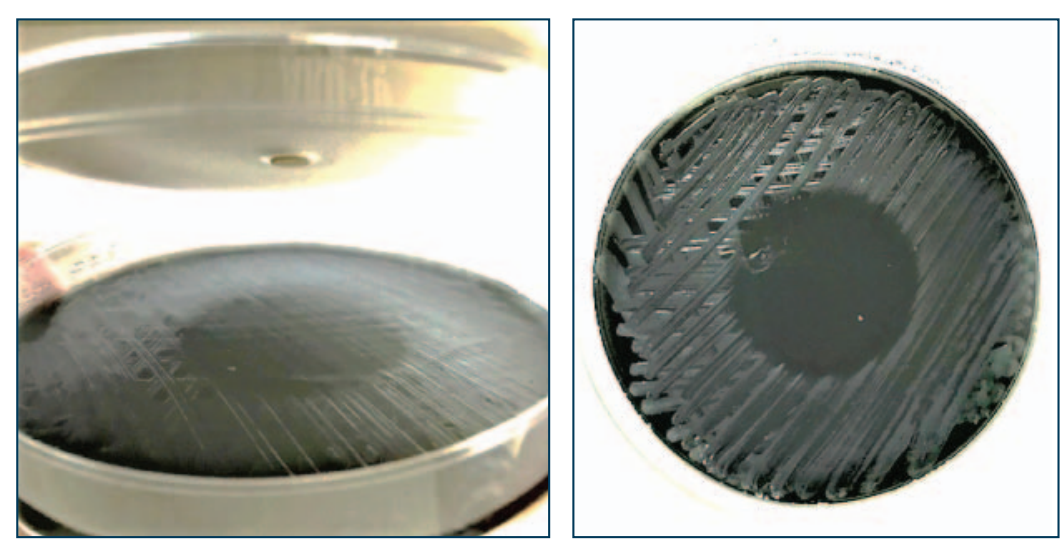

results were obtained by measuring the diameter of the zone of inhibition below the disc caused by the inhibitory action of the volatile components of the essential oils on Legionella. For each oil, the diameter of the inhibition zone was measured, and the result was expressed in millimeters. A pure DMSO control was included with each test to ensure that microbial growth was not inhibited by DMSO itself.

\section{Statistical analysis}

All experiments were performed three times in duplicate. The results are expressed as the mean \pm standard deviation. Result were statistical analyzed with Tibco Statistic 13.5.0. at a significance level of $p<0.05$. The normality of the data distribution was tested by the KolmogorovSmirnov test. The distribution was normal and parametric T-test was used.

\section{RESULTS AND DISCUSSION}

The antimicrobial properties of the volatile components of the exotic essential oils Spikenard, Niaouli, Hyssop, Palmarosa and Ravensara were investigated, and the results are shown in Figure 2. All tested essential oils showed anti-Legionella activity. The best result was obtained with the Niaouli essential oil with inhibition zone of $33.3 \mathrm{~mm}$, while the lowest result of Legionella inhibition was measured with Spikenard essential oil $(16.83 \mathrm{~mm})$. In the case of essential oils from the coastal region of Croatia (Figure 3, Table 1), the inhibition zone was statistically higher from those of exotic essential oils. The strongest antimicrobial activity of volatile components was shown by the immortelle $(H$. italicum) essential oil with an average zone of inhibition of $55.5 \mathrm{~mm}$. Sage (S. officinalis L.) and lavander (L. hybrida L.) essential oils showed a weaker inhibitory activity with a zone of inhibition of $25.3 \mathrm{~mm}$ and $24.0 \mathrm{~mm}$, respectively (Figure 2, Table 1).

The chemical components of the essential oils were also tested separately, and it was examined whether dilution affects the antimicrobial activity of the volatile phase (Figure 4, Table 1). The antimicrobial effect of two concentrations, $100 \mathrm{mg} / \mathrm{mL}$ and $200 \mathrm{mg} / \mathrm{mL}$ was investigated. The largest zone of inhibition was caused by $\alpha$-pinene, whose zone of inhibition was almost the entire surface of the Petri dish (concentration $200 \mathrm{mg} / \mathrm{mL}$ ). $\gamma$-terpinene showed no antibacterial effect,
Figure 1.

The Petri dish with cellulose disc soaked with essential oil (left) and zone of inhibition made by volatile components of essential oil (right).

\section{All tested essential oils} showed anti-Legionella activity. The best result was obtained with the Niaouli essential oil with inhibition zone of $33.3 \mathrm{~mm}$, while the lowest result of Legionella inhibition was measured with Spikenard essential oil (16.83 mm). 
Figure 2.

Antimicrobial activity of volatile components of an exotic essential oil at concentrations of $200 \mathrm{mg} / \mathrm{mL}$. The results are expressed as a mean value \pm SD of a minimum of three repeated experiments.

Figure 3.

Antimicrobial activity of volatile essential oils of coastal region of

Croatia at concentrations of $200 \mathrm{mg} / \mathrm{mL}$. The results are expressed as a mean value \pm SD of a minimum of three repeated experiments.

Figure 4.

Antimicrobial activity of volatile active components at concentrations of $200 \mathrm{mg} / \mathrm{mL}$ and $100 \mathrm{mg} / \mathrm{ml}$. The results are expressed as a mean value $\pm \mathrm{SD}$ of a minimum of three repeated experiments. Lowercase letters on top shows statistical significance $(p<0.05)$

Since essential oils are complex mixtures of many phytochemicals, it is very difficult to determine which of them is responsible for the antimicrobial activity.
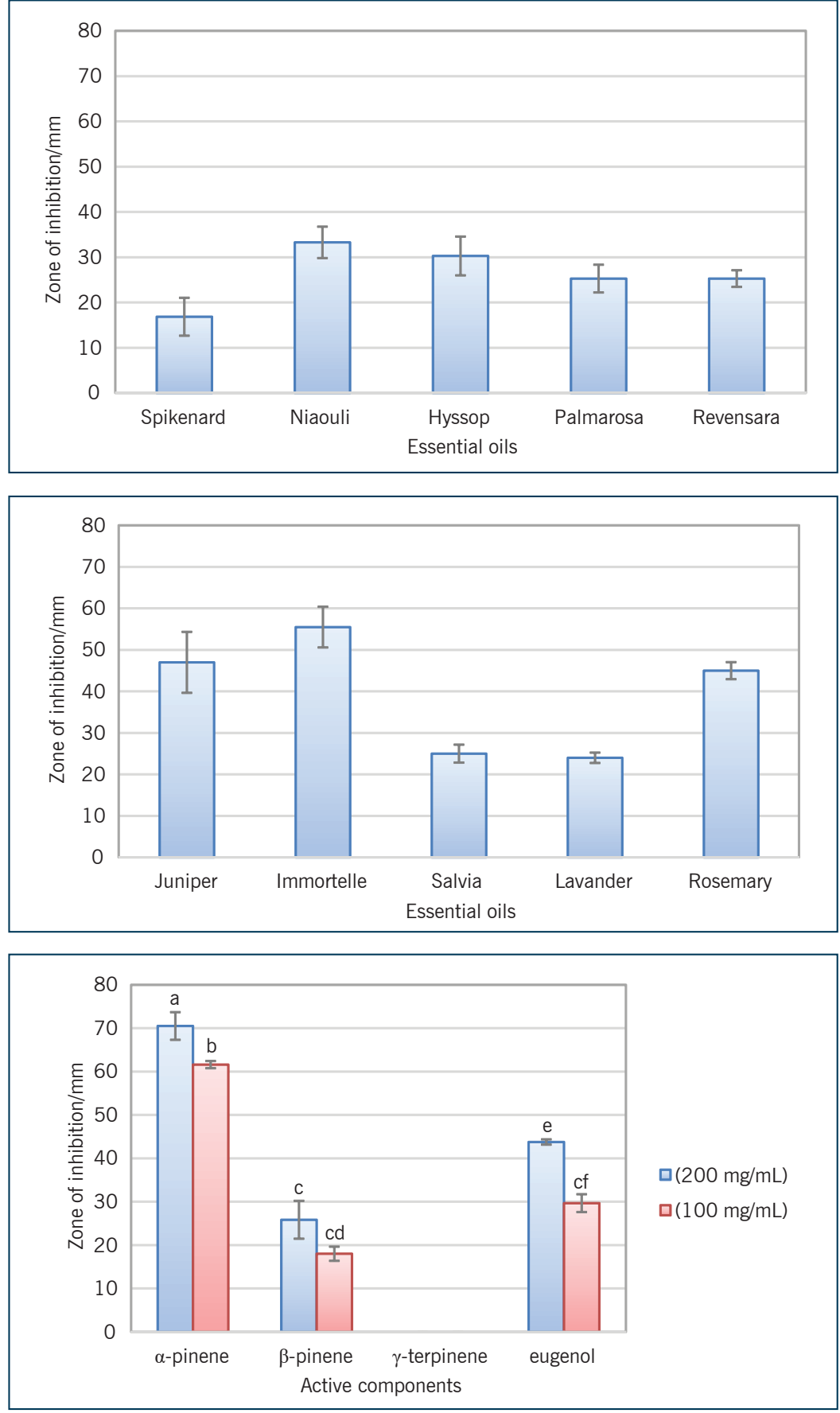

and we did not detect a zone of inhibition. Eugenol and $\beta$-pinene showed a statistically weaker effect than $\alpha$-pinene, with a higher concentration of the test compound (concentration $200 \mathrm{mg} / \mathrm{mL}$ ) showing a better antibacterial effect.

Since essential oils are complex mixtures of many phytochemicals, it is very difficult to determine which of them is responsible for the antimicrobial activity. Furthermore, it is also important to know ratios of individual components present in essential oil as well as their synergistic or antagonistic activity. Numerous studies have shown the antimicrobial properties of various essential oils on bacteria, however in most studies essential oils have been added to the medium in which the test was performed. The higher susceptibility of Gram-positive bacteria when 
Table 1 . Antimicrobial activity of volatile phase of essential oils and active components

\begin{tabular}{|l|c|}
\hline \multicolumn{1}{|c|}{ Essential oils } & Zone of inhibition $(\mathrm{mm}) \pm$ SD \\
\hline Exotic essential oils & $16,83 \pm 4,19$ \\
\hline Nard & $33,27 \pm 3,47$ \\
\hline Niauli & $30,27 \pm 4,29$ \\
\hline Isop & $25,27 \pm 3,06$ \\
\hline Palmerosa & $25,27 \pm 1,84$ \\
\hline Revensara & \\
\hline Mediterranean essential oilss & $47,00 \pm 7,35$ \\
\hline Juniper & $55,83 \pm 4,90$ \\
\hline Immortelle & $23,00 \pm 2,16$ \\
\hline Sage & $25,33 \pm 1,25$ \\
\hline Lavander & $42,33 \pm 2,05$ \\
\hline Rosemary & \\
\hline Volatile components & $70,50 \pm 3,19$ \\
\hline$\alpha$-pinene $(200 \mathrm{mg} / \mathrm{mL})$ & $25,83 \pm 4,37$ \\
\hline$\beta$-pinene $(200 \mathrm{mg} / \mathrm{mL})$ & 0,00 \\
\hline$\gamma$-terpinene $(200 \mathrm{mg} / \mathrm{mL})$ & $43,77 \pm 0,61$ \\
\hline eugenol $(200 \mathrm{mg} / \mathrm{mL})$ & $61,60 \pm 0,83$ \\
\hline$\alpha$-pinene $(100 \mathrm{mg} / \mathrm{mL})$ & $18,00 \pm 1,63$ \\
\hline$\beta$-pinene $(100 \mathrm{mg} / \mathrm{mL})$ & 0,00 \\
\hline$\gamma$-terpinene $(100 \mathrm{mg} / \mathrm{mL})$ & $29,67 \pm 2,05$ \\
\hline eugenol $(100 \mathrm{mg} / \mathrm{mL})$ & \\
\hline & \\
\hline
\end{tabular}

compared with Gram-negative strains was found, and a large variability among essential oils in the antibacterial potential has also been observed [7-10].

The main advantage of essential oils is that they do not enhance antibiotic resistance with the long-term use what is the case for synthetic antibiotics, and they showed synergy in antimicrobial activity with conventional antibiotics [11-13]. For this reason, majority of studies carried out on extracts and pure components isolated from essential oils analyzing their antibacterial activities.

Volatile Organic Compounds (VOCs) emitted by plants or essential oils are largely lipophilic products with molecular masses under $300 \mathrm{Da}$. The vast majority are isoprenoids, including hemiterpenes (C5H8) such as isoprene, monoterpenes $(\mathrm{C} 1 \mathrm{OH} 16)$, irregular acyclic homoterpenes (C11H18 or $\mathrm{C} 16 \mathrm{H} 26)$, and sesquiterpenes (C15H24) [14].

Research into the antimicrobial properties of volatile components of essential oils is rare. Laird and Phillips showed that the use of essential oil vapors in food relates to their antimicrobial activity against food pathogens and food spoilage microorganisms also [15]. Advantage of application of essential oil vapor phase, is that the components are dispersed and tend not to affect the organoleptic properties of the food like liquid essential oil. A study by Nedorostova et al. (2009) showed some antibacterial activity of 27 different essential oils vapors against five foodborne pathogens (Escherichia coli, Listeria monocytogenes, Salmonella enterica ssp. enteriditis, Staphylococcus aureus and Pseudomonas aeruginosa) using the disc volatilization method [16].
The main advantage of essential oils is that they do not enhance antibiotic resistance with the long-term use what is the case for synthetic antibiotics, and they showed synergy in antimicrobial activity with conventional antibiotics.

Advantage of application of essential oil vapor phase, is that the components are dispersed and tend not to affect the organoleptic properties of the food like liquid essential oil. 
Our results showed that $\alpha$-pinene showed a stronger effect on Legionella growth inhibitions.

All tested essential oils have the great potential to be used

as a volatile antibacterial agent to control legionellosis

and could be used as air purifiers in various rooms in hotels and spas.

Exotic essential oil with highest anti-Legionella activity was Niaouli essential oil, and the best antiLegionella activity among Mediterranean essential oils have Immortelle essential oil.
The antimicrobial activity of essential oils on Legionella has been poorly investigated. Chang et al. examined the antimicrobial activity of essential oils extracted from Cinnamomum osmophloeum leaves and Cryptomeria japonica and its major constituent, cinnamaldehyde, possess strong antiLegionella activities [17]. We have not found data on the antimicrobial activity of volatile phase of essential oils on Legionella. Since $\alpha$-pinene shows high anti-Legionella activity one can assume that essential oil with high proportion of this component will give such activity. Ramanoelina et al. demonstrate that essential oil of Niaouli ( $M$. quinquenervia) have high $\alpha$-pinene [18] content and it can be cause of high anti-Legionella activity as is shown in figure 2. Research conducted by Han et al. shows that Immortelle essential oil also have high percentage of $\alpha$-pinene [19]. Our research has shown a strong antimicrobial activity of volatile components of essential oils that predominantly have a $\alpha$-pinene in their composition. Alpha-pinene is the most widely encountered terpenoid in nature and is highly repellant to insects. There are two structural isomers of pinene found in nature: $\alpha$-pinene and $\beta$-pinene [20]. The antimicrobial activities of the isomers of pinene was shown against different bacterial and fungal species $[20,21]$.

Our results showed that $\alpha$-pinene showed a stronger effect on Legionella growth inhibitions. Reason why $\gamma$-terpinene did not show any antiLegionella activity could be that this compound on its own has no antimicrobial activity. All tested essential oils have the great potential to be used as a volatile antibacterial agent to control legionellosis and could be used as air purifiers in various rooms in hotels and spas. Furthermore, the potentially synergistic effect of volatile components of different combinations of essential oils remains to be investigated.

\section{CONCLUSION}

Wide use of essential oils demands a scientific background so antimicrobial activity of essential oil is examined all over the world. Exotic essential oil with highest anti-Legionella activity was Niaouli essential oil, and the best anti-Legionella activity among Mediterranean essential oils have Immortelle essential oil. Chemical compound that shows significant highest anti-Legionella activity was $\alpha$-pinene and essential oils with strongest anti-Legionella activity are timely the ones with highest proportion of this compound. Essential oils show great benefits as antimicrobial agents and different approach to their use for this purpose is to be examined.

\section{Acknowledgments}

The described research was funded by the University of Rijeka grant uniri-biomed-18-171.

Conflicts of Interest: The authors declare no conflict of interest. The funders had no role in the design of the study; in the collection, analyses, or interpretation of data; in the writing of the manuscript, or in the decision to publish the results. 


\section{REFERENCES}

[1] Fraiser Dw. et al. Legionnaires disease description of epidemic pneumonia. NEJM.1997;22:1189-97.

[2] Benitez AJ., Winchell JM. Clinical application of a multiplex Real-Time PCR assay for simultaneous detection of Legionella species. Legionella pneumophila, and Legionella pneumophila serogroup 1. JCM. 2013; 348-51.

[3] Bartam J. et al. Legionella and prevention of Legionellosis. WHO. 2007.

[4] Kerbel W. et al. Recognition, Evaluation, and control of Legionella in building water system. Falls Church, VA, USA: industrial Hygiene Association. 2015.

[5] Winska K. et al. Essential oils as antimicrobial agents - Myth or real alternative? Molecules. 2019;24(11):2130.

[6] Lopez P. et al. Solid and vapor-phase antimicrobial activities of six essential oils: susceptibiliti of selectrd foodborne bacterial and fungal strains. J. Agric. Food Chem. 2005;53:6939-46.

[7] Murbach Tele Andrade BF. et al. Antimicrobial activity of essential oils. JEOR. 2013;26:34-40.

[8] Malenica Staver M. et al. In vitro antiproliferative and antimicrobial activityof the essential oil from the flowers and leavesof helichrysum italicum (roth) g. Don growing incentral dalmatia (Croatia). JEOBP. 2018;21:77-91.

[9] Inouye S., Takizawa T., Yamagucchi H. Antibacterial activity of essential oils and their major constituents against respiratory tract pathogens by gaseous contact. J. Antimicrob. Chemother. 2017;47(5):565-73.

[10] Shoajee-Aliabdi S., Marzieh Hosseini S., Mirmoghtadaie L. Antimicrobial activity of essential oil. Essential oils in food procesing: Chemistry, Safety and Applications. 2017;191-229.

[11] Aleksic V. et al. Synergistic effect of Myrtus communis L. essential oils and conventional antibiotics against multi-drug resistant Acinetobacter baumannii wound isolates. Phytomedicine. 2014;12(21):1666-74.

[12] Knezevic P. et al. Antimicrobial activity of Eucalyptus camaldulensis essential oils and their interactions with conventional antimicrobial agents against multi-drug resistant Acinetobacter baumannii. J Ethnopharmacol. 2016;178:125-36.

[13] Duarte A. et al. Synergistic activity of coriander oil and conventional antibiotics against Acinetobacter baumannii. Phytomedicine. 2012: 19:236-8.

[14] Antonelli M. et al. Forest volatile organic compounds and their effects on human health: a state-of-the-art review. Int. J. Environ. Res. Public Health. 2020;17(18):6506.

[15] Laird K., Phillips C. Vapour phase: a potential future use for essential oils asantimicrobials? Lett. Appl. Microbiol. 2012;3(54):169-74.

[16] Nedorstova L. et al. Antimicrobial properties of selected essential oils in vapuor phase against foodborne bacteria. Food control. 2009;20:15760.

[17] Chang CW. et al. Antibacterial activities of plant essential oils against Legionella pneumophila. Wather Res. 2008;42:278-86.

[18] Ramanoelina PA., Bianchini JP., Andriantsiferana M. Chemical Composition of Niaouli Essential Oils from Madagascar. J. Essent. Oil Res. 1992; 657-8.

[19] Han X. et al. Chemical composition analysis and in vitro biological activities of ten essential oils in human skin cells. Biochim. Open. 2017;5:1-7.

[20] Rivas da Silva AC. et al. Biological activities of a-pinene and $\beta$-pinene enantiomers. Molecules. 2012;17:6305-16.

[21] de Sousa EL. et al. Antibacterial activity and time-kill kinetics of positive enantiomer of $\alpha$-pinene against strains of staphylococcus aureus and escherichia coli. Curr Top Med Chem. 2018; 18(11)917-24. 